\title{
PROPORSIONALITAS PUTUSAN HAKIM BERDASARKAN IDE KESEIMBANGAN
}

\author{
Endri ${ }^{1}$, Suryadi $^{2}$, Pery Rehendra Sucipta ${ }^{3}$ \\ ${ }^{123}$ Program Studi Ilmu Hukum, Fakultas Ilmu Sosial dan Ilmu Politik \\ Universitas Maritim Raja Ali Haji, Jalan Raya Dompak, Tanjungpinang, Kepulauan Riau 29100 \\ Email: endrieshaemha@gmail.com
}

\begin{abstract}
The law enforcement process is a long series in the criminal justice system which culminates in a judge's ruling. Judges 'verdicts are oral and written judges' statements which are open to the public from a case whether to convict a criminal, be free or release based on various legal considerations. Everyone can judge the judge's decision based on their respective roles but with respect to the decision. Sometimes judges' decisions can be accepted by the public, but there are also those who become polemic especially if it has received public attention. Most of them get public attention because they are considered to not reflect justice, disproportionate and not with complete consideration. Therefore, this paper explores the problem by looking at the basic considerations so that the judge's decision becomes proportional based on the idea of balance using normative research. The result shows that judges tend to be incomplete considering both the interests of victims, perpetrators, the community and the social impact of the decision. To overcome this, there needs to be an idea of a balance between formal legality and local wisdom, between aspects of legal certainty, flexibility and justice, and a balance between the interests of the perpetrator and the victim (community).
\end{abstract}

Keywords; Judge's Decision, Proportionality, Idea Of Balance

\begin{abstract}
Abstrak
Proses penegakan hukum merupakan rangkaian yang panjang dalam sistem peradilan pidana yang puncaknya pada putusan hakim. Putusan hakim merupakan pernyataan hakim secara lisan dan tulisan yang terbuka untuk umum dari suatu perkara apakah akan menjatuhkan pidana, bebas atau melepaskan berdasarkan berbagai pertimbangan hukumnya. Setiap orang dapat menilai putusan hakim berdasarkan perannya masing-masing tapi dengan tetap menghormati putusan itu. Terkadang putusan hakim dapat diterima oleh masyarakat namun juga ada yang menjadi polemik apalagi sudah mendapat sorotan publik. Kebanyakan yang mendapat sorotan publik karena dinilai kurang mencerminkan keadilan, tidak proporsional dan tidak dengan pertimbangan yang lengkap. Oleh sebab itu, tulisan ini menggali masalah tersebut dengan melihat dasar pertimbangan agar putusan hakim menjadi proporsional berdasarkan ide keseimbangan dengan menggunakan penelitian normatif. Hasilnya terlihat hakim cenderung kurang lengkap mempertimbangkan baik kepentingan korban, pelaku, masyarakat dan dampak
\end{abstract}


sosial dari putusan itu. Untuk mengatasinya maka perlu meperhatikan ide keseimbangan antara legalitas formal dan keafiran lokal masyarakat, antara aspek kepastian hukum, kelenturan dan keadilan, dan keseimbangan antara kepentingan si pelaku dengan korban (masyarakat).

Kata Kunci; Putusan hakim, proporsionalitas, ide keseimbangan

\section{PENDAHULUAN}

Masalah putusan hakim merupakan masalah yang selalu menarik diperdebatkan, tergantung persepsi dan cara padang masing-masing individu. Tidak semua akan setuju setiap putusan hakim karena paling tidak ada dua pihak yang saling berlawan, dan dalam putusan tentunya satu pihak akan ada yang menang dan ada yang kalah. Setiap putusan hakim harus dihormati oleh setiap orang sebagai produk institusi yang sah, namun setelah putusan itu sudah bisa diakses dan menjadi hak publik, maka beberapa substansi putusan sudah bisa diperdebatkan sesuai dengan peran masing-masing. Bagi pihak yang kalah dapat melakukan upaya hukum, begitu pula masyarakat, praktisi dan akademisi juga dapat mengkritisi atau memberi masukan baik dengan diskusi/seminar maupun tulisan dengan harapan menjadi lebih baik.

Putusan hakim yang seringkali menjadi polemik biasanya tentang adil atau tidaknya putusan, karena setiap orang mempunyai penilaian dan ukuran yang berbeda. Suatu putusan dapat dilihat dari alasan dan dasar putusan serta norma hukum yang digunakan sehingga ada yang mengatakan sudah adil atau ada mengatakan tidak proporsional. Proporsional artinya sesuai dengan proporsi; sebanding; seimbang; berimbang ${ }^{1}$ misalnya antara perbuatan pidana dengan sanksi yang dijatuhkan, namun ukuran proporsional ini cukup sulit dicapai apabila menghadapi suatu kasus. Proporsional atau dapat juga dikatakan keseimbangan dalam menjatuhkan putusan yaitu antara perbuatan pidana dengan sanksi yang dijatuhkan. Gambaran ide keseimbangan ini akan terlihat antara lain dari argumentasi hukum hakim yang disebut juga dengan penalaran hukum (legal reasoning) ${ }^{2}$ sebagai dasar dalam putusannya. Menurut Shidarta, puncak dari proses

\footnotetext{
${ }^{1}$ Lihat Kamus Besar Bahasa Indonesia (KBBI), dapat ditelusuri pada https://www.kbbi.web.id/proporsional 2 Shidarta, Argumentasi Hakim Dalam Beberapa Contoh Kasus Penodaan Agama, 2018, Dapat ditelusuri pada https://business-law.binus.ac.id/2018/07/10/argumentasi-hakim-dalam-beberapa-contoh-kasus-penodaanagama/ diakses pada 27 April 2020
} 
penalaran hukum ini memang ada pada penalaran hukum yang dibuat oleh hakim di dalam putusannya. ${ }^{3}$

Konstruksi dari suatu putusan akan terlihat dari pertimbangan hakim yang kadang tidak berimbang atau tidak lengkap menilai suatu perkara. Loebby Loqman mengatakan bahwa, penjatuhan pidana janganlah didasarkan sebagai suatu 'ukuran pabrik' akan tetapi haruslah sebagai suatu tailor made, baik dengan melihat variabel pribadinya, variabel delik, variabel sanksinya maupun variabel kebudayaan. Lebih lanjut beliau mengemukakan, bahwa seorang hakim tidaklah selesai tugasnya dengan menjatuhkan suatu pidana dalam suatu perkara, akan tetapi haruslah dapat mengetahui apakah memang pemidanaan yang dijatuhkan sesuai. ${ }^{4}$

Pemikiran tersebut adalah sangat logis dengan mengharapkan putusan hakim yang benar-benar dapat dipertanggungjawabkan, independen, dan bebas dari tekanan. Hakim merupakan pusat peradilan yang menjadi tempat pencari keadilan, sehingga setiap pertimbangan dalam putusannya benar-benar sesuai keadilan berdasarkan Ketuhanan Yang Maha Esa. Dengan demikian, jaminan independensi dan kemerdekaan dalam memutus setiap kasus adalah hal sangat penting karena tidak sedikit putusan menjadi polemik ditengah masyarakat. Hal itu disebabkan karena tidak melihat secara lengkap pertimbangan baik kepentingan pelaku, korban dan masyarakat serta dampak sosial lainnya. Berdasarkan hal itu, terkait dengan persoalan ini maka memunculkan dua permasalahan pokok dalam tulisan ini, pertama, bagaimana dasar pertimbangan hakim dalam memutus suatu perkara berdasarkan hukum dan keyakinannya? kedua, bagaimana konsep proporsionalitas putusan hakim berdasarkan ide keseimbangan?

\section{METODE PENELITIAN}

Penulisan ini menggunakan motode penelitian hukum normatif atau doktrinal yaitu dengan pendekatan perundang-undangan, pendekatan konseptual. Penelitian doktrinal merupakan penelitian dalam bidang hukum yang memposisikan hukum adalah sistem norma yang memfokuskan pada studi dokumen dalam penelitian

\footnotetext{
3 Ibid.

${ }^{4}$ Loebby Loqman, Pemidanaan Yang Bagaimana, Jurnal Hukum dan Pembangunan, Fakultas Hukum Universitas Indonesia, Vol 14, No 6, 1984, hlm. 582. Dapat ditelusuri pada http://jhp.ui.ac.id/index.php/home/article/view/1088/1011.
} 
kepustakaan. Penelitian ini menekankan pada data sekunder yaitu bahan hukum primer dalam perundang-undangan, sedangkan bahan hukum sekunder diperoleh dari buku-buku teks, jurnal dan kasus-kasus. Proses pengumpulan bahan-bahan hukum dilakukan dengan membaca dan memahami literatur dan dokumen yang berhubungan dengan permasalahan pokok dalam tulisan ini dan dianalisis secara seksama. Analisis semua bahan tersebut dihubungkan pada ide dasar tulisan ini untuk menggambarkan proporsionalitas sebuah putusan hakim yang berdasarkan ide keseimbangan.

\section{PEMBAHASAN DAN ANALISIS}

\subsection{Pertimbangan Hakim Dalam Memutus Perkara Berdasarkan Hukum Dan Keyakinannya}

Pertimbangan hukum dalam suatu putusan perkara pidana merupakan bentuk pertanggungjawaban hakim ${ }^{5}$ kepada masyarakat, korban, pelaku dan kepada Tuhan. Oleh karena itu, pertimbangan putusan yang termuat dalam amar putusan merupakan dasar untuk memutus apakah akan menghukum, membebaskan dan melepaskan sesuai dengan hukum dan keyakinan hakim yang dimuat dalam putusan dengan mempertimbangkan berbagai aspek sesuai dengan karakter kasus.

Putusan hakim merupakan mahkota bagi hakim bertalian dengan tugasnya dalam memutus perkara. Pertimbangan hukum putusan merupakan bagian paling penting karena memuat pernyataan hakim tentang hukum yang akan diberlakukan dalam memeriksa, memutus dan menyelesaikan suatu perkara atau sengketa yang dihadapkan kepadanya. ${ }^{6}$ Sebelum menjatuhkan putusan, ada rangkaian proses yang cukup panjang dari penyelidikan, penyidikan, penuntutan dan puncaknya adalah putusan hakim. Setiap rangkaian ini akan ada argumentasi hukum atau penalaran hukum pada setiap lembaga (kepolisian, kejaksaan atau lembaga lainnya), dan muaranya ada pada lembaga pengadilan khususnya pada hakim yang akan memutus. Dengan demikian hakim merupakan puncak dari peradilan dan sekaligus juga puncak penalaran hukum sebagai dasar dalam mengambil keputusan.

\footnotetext{
5 Dwi Hananta, Pertimbangan Keadaan-Keadaan Meringankan dan Memberatkan Dalam Penjatuhan Pidana, Jurnal Hukum dan Peradilan, Volume 7, Nomor 1 Maret 2018, hlm. 88 ${ }^{6}$ Ibid.
} 
Penalaran hukum hakim dipengaruhi oleh faktor-faktor di luar dirinya, yang tidak hanya terbatas pada perundang-undangan saja, melainkan juga nilai-nilai hukum dan rasa keadilan yang hidup dalam masyarakat. ${ }^{7}$ Kombinasi inilah yang akan mentukan putusan secara adil berdasarkan hukum dengan memperhatikan perbuatan pelaku, fakta persidangan, kerugian yang dialami korban, ancaman pidana serta keyakinan hakim atas serangkaian dari proses pembuktian itu. Ada banyak faktor yang harus diperhatikan agar hakim yakin atas suatu perbuatan pidana, tapi secara umum biasanya akan tertuju pada perbuatan pidana secara objektif dan orang yang melakukan pidana secara subjektif. Untuk melihat pertimbangan hukum suatu putusan, dapat dilihat dari putusan pengadilan No.574 K/Pid.Sus/2018/MA dengan putusan No. 83 PK/PID.SUS/20198, dan putusan pengadilan No. 374/ Pid.Sus/ 2017/PN.Tpg ${ }^{9}$ berikut ini:

\section{Kasus pertama:}

Kronoligis singkat, bahwa (BNM) dituding menyebarkan rekaman percakapan mesum yang di dakwakan kepadanya dengan Pasal 27 ayat (1) juncto Pasal 45 ayat (1) UU No. 11 Tahun 2008 tentang Informasi dan Transaksi Elektronik (ITE) dengan pidana penjara maksimal 6 (enam) tahun dan/atau denda maksimal 1 (satu) miliar rupiah. Pada tingkat pengadilan pertama BNM dinyatakan bebas, namun jaksa mengajukan kasasi. Dalam putusan kasasi tersebut, Mahkamah Agung (MA) menyatakan BNM bersalah dengan pidana penjara 6 (enam) bulan dan denda 500 (lima ratus) juta rupiah. Karena merasa dirugikan BNM pun mengajukan Peninjauan Kembali (PK), namun ditolak oleh MA. Pada akhirnya Presiden Joko Widodo memberikan amnesti pada BNM dan kasus ini sempat heboh karena menjadi berita nasional.

Apabila dilihat dari tuntutan jaksa pada Kejaksaan Negeri Mataram pada tanggal 14 Juni 2017 yang intinya adalah menyatakan terdakwa atas nama BNM terbukti secara sah dan meyakinkan bersalah melanggar Pasal 27 ayat (1) jo. Pasal 45 ayat (1) UU ITE serta menjatuhkan 6 (enam) bulan pidana penjara dan denda sebanyak 500 (lima ratus) juta rupiah dengan subsidiair kurungan

\footnotetext{
7 Ibid.

${ }^{8}$ Kedua Putusan Mahkamah Agung tersebut adalah Putusan Kasasi (No.574 K/Pid.Sus/2018/MA) dan Putusan Peninjauan Kembali (No. 83 PK/PID.SUS/2019) atas nama BNM

${ }^{9}$ Lihat Putusan Pengadilan Negeri Tanjungpinang No. 374 /Pid.Sus/ 2017/ PN.Tpg atas nama TH alias A
} 
selama 3 (tiga) bulan. Berdasarkan tututan tersebut maka BNM dinyatakan tidak terbukti berdasarkan putusan hakim tingkat pertama. ${ }^{10}$ Tidak terima atas putusan pengadilan tingkat pertama tersebut maka jaksa mengajukan kasasi, dan hasilnya diterima oleh Mahkamah Agung (MA) dengan menghukum BNM berdasarkan putusan No 574 K/Pid.Sus/2018/MA yang intinya sebagai berikut: ${ }^{11}$

a) Menyatakan terdakwa BNM terbukti secara sah dan meyakinkan bersalah melakukan tindak pidana "tanpa hak mendistribusikan dan/atau mentransmisikan dan/atau membuat dapat diaksesnya informasi elektronik dan/atau dokumen elektronik yang memiliki muatan yang melanggar kesusilaan.

b) Menjatuhkan pidana kepada terdakwa 6 (enam) bulan pidana penjara dan pidana denda 500 (lima ratus) juta rupiah, subsisder 3 (tiga) bulan kurungan.

Berdasarkan hal di atas maka terlihat dasar pertimbangan hakim MA mengabulkan kasasi jaksa penuntut umum yang intinya sebagai berikut: ${ }^{12}$

a) Ada kekeliruan berdasarkan kesimpulan dan pertimbangan hukum yang dianggap tidak sesuai fakta hukum secara yuridis dan tidak berdasarkan fakta-fakta yang terungkap selama persidangan;

b) Bahwa tujuan pemidanaan UU ITE sejalan dengan tujuan pemerintah dalam melakukan pengembangan teknologi melalui infrastruktur hukum dan pengaturannya, sehingga diharapkan pemanfaatan tehnologi dan informasi dapat dilakukan secara aman untuk mencegah penyalahgunaan dengan memperhatikan nilai-nilai agama, sosial dan budaya masyarakat Indonesia, karena tidak dapat dipungkiri bahwa tehnologi saat ini menjadi pedang bermata dua, karena selain memberikan kontribusi bagi peningkatan kesejahteraan dan kemajuan peradaban manusia, sekaligus menjadi media atau sarana yang paling efektif untuk melakukan perbuatan melawan hukum;

c) Penjatuhan pidana khususnya terhadap terdakwa diharapkan dapat menjadi pembelajaran maupun pada masyarakat luas untuk berhatihati menggunakan media elektronik;

d) Keadaan atau hal-hal yang memberatkan terdakwa adalah karir saksi $M$ terhenti, dan keluarganya malu. Sedangkan hal-hal yang meringankan terdakwa adalah tidak pernah dipidana dan mempunyai tanggungan 3 (tiga) orang anak.

\footnotetext{
${ }^{10}$ Lihat Putusan Pengadilan Negeri Mataram pada tanggal 26 Juli 2017, No. 256/ Pid. sus/PN Mataram atas nama BNM

11 Diringkas dari Putusan Putusan Kasasi Mahkamah Agung Tersebut No.574 K/Pid.Sus/2018/MA atas nama BNM

12 Ibid. Uraian pertimbangan hakim dalam kasus atas nama BNM yang mengabulkan Jaksa Penuntut Umum (JPU)
} 
BNM merasa dirugikan, maka beliau mengajukan Peninjauan Kembali (PK) namun ditolak MA berdasarkan No 83 PK/PID.SUS/2019. Adapun alasan petimbangan majelis hakim menolak PK dari terpidana BNM yang intinya sebagai berikut: ${ }^{13}$

a) Alasan peninjauan kembali dari terpidana yaitu adanya kekeliruan yang nyata tidak dapat dibenarkan karena pertimbangan dalam penerapan hukum sebagaimana pasal yang didakwakan

b) Perbuatan Pemohon Peninjauan Kembali/Terpidana terbukti memberikan informasi elektronik kepada orang lain yang mengandung muatan kesusilaan;

c) Pemohon Peninjauan Kembali/Terpidana selalu menolak untuk memberikan isi rekaman tersebut sehingga dapat disimpulkan bahwa Pemohon Peninjauan Kembali/Terpidana mengetahui dan menyadari konsekuensi jika Pemohon Peninjauan Kembali/Terpidana memberikannya kepada orang lain;

d) Terpidana juga dengan sengaja dan dalam keadaan sadar serta tidak di bawah tekanan berjanji bertemu dengan Saksi IM,... selanjutnya hasil rekaman tersebut ditansmisikan/ditransfer ke laptop milik saksi IM dan terbukti kemudian konten yang ditransmisikan/ditransfer tersebut tersebar ke pihak-pihak lainnya sebagaimana telah dipertimbangkan secara jelas dan lengkap oleh Judex Juris yang mengakibatkan kerugian moril pada saksi korban (M) dan keluarganya serta keluarga L;

e) Dan seterusnya.

\section{Kasus kedua.}

Putusan No 374/Pid.Sus/2017/PN Tpg dengan terdakwa TH, swasta (Dirut PT PL). Kasus ini berawal ketika Satreskrim Polres Tanjungpinang menggrebek gudang tempat "pengoplosan/mencampur" beras milik HT. HT ditangkap 23 September 2017, ditahan 24 September - 13 Oktober 2017; Penangguhan Penahanan sejak tanggal 30 September 2017; Tahanan Rumah sejak tanggal 1 - 20 Nopember 2017; Penahanan oleh Hakim PN Tpg (Tahanan RUMAH) sejak tanggal 13 Nopember -12 Desember 2017; Perpanjangan Penahanan oleh Waka PN Tpg (Tahanan RUMAH) sejak tanggal 13 Desember 2017 - 10 Pebruari 2018. Dituntut dengan pidana penjara selama satu bulan atau denda dua ratus juta rupiah, dan akhirnya hakim menjatuhkan pidana

13 Uraian singkat pertimbangan hakim menolak Peninjauan Kembali (PK) yang diajukan BNM berdasarkan putusan No. 83 PK/PID.SUS/2019 
denda 150 (seratus lima puluh) juta rupiah dengan subsider kurungan 1 (satu) bulan kurungan pengganti.

Untuk lebih jelas, berikut ini gambaran dari dakwaan, tuntutan dan putusan yang terangkum dalam putusan hakim No 374/Pid.Sus/2017/PN Tpg, yaitu: ${ }^{14}$

1. Dakwaan(dakwaan alternatif)

Berdasarkan surat dakwaan No. Reg. Perkara: PDM-175/ TG. PIN/ Epp. 1/ 11/ 2017 tanggal 11 Nopember 2017 yang intinya menjelaskan sebagai berikut:

Bahwa terdakwa TH selaku Direktur Utama PT. PL, pada waktu mulai dari bulan Juli tahun 2017 sampai dengan tanggal 22 September 2017, atau setidak-tidaknya pada bulan Juli 2017 sampai dengan tanggal 22 September $2017 \ldots$ atau setidak-tidaknya pada tempat-tempat lain yang masih termasuk dalam Daerah Hukum PN Tpg, bahwa. Pertama, dengan sengaja membuka kemasan akhir pangan untuk dikemas kembali dan diperdagangkan sebagaimana dimaksud dalam Pasal 84 ayat (1) UU RI Nomor: 18 Tahun 2012, dilakukan dengan cara: Terdakwa memerintahkan saksi JS selaku karyawan terdakwa di bagian gudang untuk mencapur beras merk beras kita yang diproduksi/ dikemas oleh Perum Bulog dengan beras Super Roda Mas yang diproduksi oleh Berasindo Raya. Kemudian beras yang sudah dicampur dimasukkan ke dalam kantong plastik dengan ukuran 5 (lima) kg, lalu kantong plastik yang berisikan beras campuran tersebut diberi nama dengan nama "Bulog Premium 5 KG". Kemudian dijual kepada masyarakat, dan terdakwa tidak ada izin dari pihak yang berwenang untuk mengoplos atau mencampur beras tersebut. Didakwa sebagaimana diatur dan diancam pidana dalam Pasal 139 Jo. Pasal 84 ayat (1) UU No. 18 Tahun 2012 tentang Pangan, dengan ancaman pidananya penjara paling lama 5 (lima) tahun atau denda sepuluh miliar rupiah. atau, Kedua, dengan dakwaan yaitu pelaku usaha dilarang memproduksi dan/ atau memperdagangkan barang dan/ jasa yang tidak memenuhi atau tidak sesuai dengan standar yang dipersyaratkan dan ketentuan peraturan perundang-undangan. Bahwa perbuatan terdakwa sebagaimana diatur dan diancam pidana dalam Pasal 62 ayat (1) Jo. Pasal 8 ayat (1) huruf a UU No. 8 Tahun 1999 tentang Perlindungan Konsumen dengan acanman pidana penjara paling lama 5 (lima) tahun atau pidana denda paling banyak dua miliar rupiah.

2. Tuntutan

Adapun tuntutan jaksa dengan Nomor PDM 175/ TG. PIN/ Epp. 1/ 11/ 2017 tanggal 10 Januari 2017, intinya sebagai berikut:

\footnotetext{
${ }^{14}$ Uraian secara singkat, dakwaan, tuntutan, dan pertimbangan hakim dalam memutus perkara pidana atas nama
} TH berdasarkan putusan No. No 374/Pid.Sus/2017/PN Tpg 
Menyatakan terdakwa TH terbukti secara dan meyakinkan bersalah melakukan tindak pidana yaitu pelaku usaha dilarang memproduksi dan/ atau memperdagangkan barang dan/ atau jasa yang tidak memenuhi atau tidak sesuai dengan standar yang dipersyaratkan dan ketentuan peraturan perundang-undangan sebagaimana dimaksud dalam dakwaan kedua Penuntut Umum yaitu melanggar Pasal 62 ayat (1) Jo Pasal 8 ayat (1) huruf a UU RI Nomor 8 tahun 1999 tentang Perlindungan Konsumen. Menjatuhkan pidana terhadap Terdakwa $\mathrm{TH}$, dengan pidana penjara selama 1 (satu) bulan dikurangi selama berada dalam tahanan atau denda sebanyak Rp. 200.000.000,- (dua ratus juta rupiah) dengan perintah agar terdakwa tetap ditahan; dan menetapkan supaya terdakwa dibebani membayar biaya perkara sebesar Rp 2.000,- (dua ribu rupiah).

3. Putusan Hakim Nomor 374/ Pid.Sus/ 2017/ PN. Tpg:

a) Menyatakan terdakwa TH telah terbukti secara sah dan meyakinkan bersalah melakukan tindak pidana "memperdagangkan barang yang tidak memenuhi atau tidak sesuai dengan standar yang dipersyaratkan dan Ketentuan Peraturan perundang-undangan".

b) Menjatuhkan pidana terhadap terdakwa dengan pidana denda 150 (seratus lima puluh) juta rupiah dengan subside selama 1 (satu) bulan kurungan pengganti.

c) Memerintahkan agar terdakwa segera dikeluarkan dari Tahanan Rumah;

Berdasarkan uraian di atas, maka hakim dalam pertimbangannya adalah sebagai berikut:

1. Menimbang, bahwa oleh karena dakwaan dari Penuntut Umum tersebut berbentuk alternatif, maka Majelis Hakim akan membuktikan dengan cara memilih langsung salah satu dari dakwaan Penuntut Umum di atas berdasarkan fakta-fakta di persidangan yaitu dakwaan kedua Pasal 62 ayat (1) Jo. Pasal 8 ayat (1) huruf a UU No. 8 Tahun 1999 tentang Perlindungan Konsumen dengan unsur-unsurnya adalah pelaku usaha, dilarang memproduksi dan/ atau memperdagangkan barang dan/ atau jasa yang tidak memenuhi atau tidak sesuai dengan standar yang dipersyaratkan dan sesuai ketentuan UU";

2. Menimbang; hal-hal yang memberatkan: -(Perbuatan terdakwa telah merugikan orang lain). Hal-hal yang meringankan: - (Terdakwa sopan selama di persidangan; - Terdakwa belum pernah dihukum; - Terdakwa mengakui dan menyesali perbuatannya; - Terdakwa berjanji tidak akan mengulangi perbuatannya; - Terdakwa sebagai tulang punggung keluarga dan memiliki tanggungan yaitu istri dan anak-anak);

3. Menimbang, bahwa tujuan pemidanaan bukanlah suatu pembalasan melainkan merupakan pembinaan bagi terdakwa yang telah berbuat salah sehingga diharapkan agar nantinya dapat kembali lagi ke tengah-tengah masyarakat setelah dapat memperbaiki kesalahannya oleh karena itu Majelis Hakim sependapat dengan Penuntut Umum mengenai pembuktian akan tetapi karena Penuntut Umum telah menuntut agar terdakwa dijatuhi 
pidana berupa pidana penjara atau denda sebagaimana ancaman pidana yang diatur dalam dakwaan kedua jaksa penuntut umum, maka hakim akan memilih salah satu pidana tersebut dan pidana yang akan dijatuhkan tersebut dianggap sesuai dengan perbuatan yang dilakukan terdakwa;

4. Menimbang, bahwa majelis hakim untuk menjatuhkan denda kepada terdakwa yaitu, motif terdakwa sebagai pelaku usaha dengan melakukan pencampuran beras adalah bukan semata-mata mencari keuntungan namun karena tingginya permintaan dari Konsumen di pasaran terhadap beras Bulog Premium $5 \mathrm{Kg}$, karena Bulog tidak lagi mengeluarkan Beras Premium $5 \mathrm{Kg}$ namun hanya Beras Bulog Premium $50 \mathrm{Kg}$, sehingga masyarakat kecil tidak sanggup membeli untuk membeli Beras Bulog Premium 50 Kg; - Bahwa, jangka waktu peredaran Beras Premium 5 Kg hasil pencampuran yang dilakukan oleh terdakwa tersebut relatif belum lama yaitu sekitar 3 (tiga) bulan; - Bahwa, perbuatan terdakwa selaku Pelaku Usaha dalam mencampur beras merk Beras Kita dengan kualitas premium dan beras merk Roda Mas dengan kualitas medium yang dikemas dalam kemasan plastik Beras Premium Bulog $5 \mathrm{Kg}$ tersebut menghasilkan kualitas yang lebih baik dibanding dengan Beras Premium Bulog $5 \mathrm{Kg}$ (yang diproduksi oleh Bulog) karena sebagaimana yang disebutkan oleh Ahli bahwa Beras Bulog Premium yang sebenarnya diproduksi oleh bulog adalah merupakan beras dengan kualitas medium.

Berdasarkan dua putusan di atas, maka perlu dilihat kapan orang itu bisa dipertanggungjawabkan dan seberapa jauh kesalahan yang dilakukan serta sanksi apa yang cocok atas kesalahan itu. Lebih lanjut Markus D. Dubber mengemukakan bahwa a person is criminally liable if he engages in (seseorang bertanggung jawab secara pidana apabila dia melakukan): ${ }^{15}$

1. conduct that (perbuatan itu);

a. inflicts or threatens (menimbulkan atau mengancam);

b. substantial harm to individual or public interests (kerugian substansial untuk kepentingan individu atau public)

2. without justification and (tanpa alasan pembenar, dan);

3. without excuse (tanpa alasan pemaaf).

Berdasarkan hal itu, maka terlihat dalam putusan dalam kasus yang pertama (atas nama BNM), bahwa hakim sudah memutus berdasarkan hukum dengan mempertimbangkan berbagai aspek, akan tetapi terkesan lebih mengutamakan kebenaran secara procedural/formil daripada kebenaran materil. Misalnya dari pertimbangan hakim pada peninjauan kembali yaitu terpidana menolak untuk memberikan isi rekaman tersebut sehingga hakim

15 Markus D. Dubber, An Introduction to the Model Penal Code, United States of America, Oxford University Press, 2015 hlm. 24 
dalam perkara ini menyimpulkan mengetahui dan menyadari konsekuensi jika terpidana memberikan rekaman tersebut kepada orang lain. Dalam konteks tersebut terpidana dalam keadaan ketakutan dan akhirnya merekam perbuatan jahat yang ditujukan kepada dirinya supaya suatu saat kalau dipersoalkan ada bukti yang dimiliki. Dengan demikian tidak ada niat jahat dari terpidana/BNM untuk menyebarluaskan isi rekaman tersebut melaui teknologi informasi elektronik.

Selanjutnya dalam pertimbangan lain dalam putusan tersebut dikatakan bahwa terpidana juga dengan sengaja dan dalam keadaan sadar serta tidak di bawah tekanan menyerahkan rekaman tersebut pada orang lain. Atas pertimbangan itu justru orang lain yang meminta rekaman tersebut supaya bisa diselesaikan dan ternyata tersebar. Kalaupun perbuatan tersebut secara normatif memenuhi rumusan Pasal 27 ayat (1) juncto Pasal 45 ayat (1) UU No. 11 Tahun 2008 tentang Informasi dan Transaksi Elektronik (ITE) karena dengan sadar menyerahkan pada orang lain atau karena tidak berwenang untuk merekam pembicaraan orang lain, namun seyogyanya bukan menghukum terpidana (perekam) karena dia sesungguhnya yang menjadi korban. Hal itu terlihat dari arah pembicaraan secara substansi dalam rekaman itu yang ditujukan pada terpidana/BNM. Kenyataannya itu sangat terlihat dalam salah satu pertimbangan pada putusan tingkat pertama, namun pada tingkat kasasi dan peninjauan kembali di MA justru sebaliknya yaitu terkesan menegakan hukum hanya sebatas norma atau hukum diatas kertas.

Adapun dalam kasus kedua (atas nama TH), hakim sudah berusaha untuk memperhatikan/mempertimbangkan perbuatan terdakwa, pengakuan terdakwa, hal yang memberatkan dan meringankan, tujuan pemidanaan serta memilih sanksi pidana denda adalah sanksi yang tepat namun terlihat kurang memperhatikan kerugian masyarakat dan dampak sosial dari putusan itu. Dengan menjatuhkan pidana denda hanya seratus lima puluh juta (dengan ketentuan denda tidak dibayar diganti satu bulan kurungan) dari ancaman pidana maksimal dua miliar rupiah dirasa tidak adil apabila dijatuhkan kepada seorang pengusaha, karena dengan membayar nominal uang seratusan lima puluh juta tidak akan memberikan deterrent effect/ shock therapy bagi 
terpidana seorang pengusaha, dan dengan mudah sekali untuk membayar denda sebanyak itu. Dampaknya, bukan tidak mungkin perbuatan "mengoplos/mencampur" beras yang bertentangan dengan hukum itu diulangi atau ditiru orang lain.

\subsection{Proporsionalitas putusan hakim berdasarkan ide keseimbangan}

Berdasarkan yang dikemukakan di atas, bahwa putusan hakim harus berdasarkan hukum dan keyakinannya, akan tetapi harus berdasarkan pertimbangan yang lengkap supaya putusan yang dikeluarkan mencerminkan keadilan bagi semua. Menjatuhkan putusan ini sangat dipengaruhi cara pandang dan tujuan pemidanaan hakim dalam menilai masing-masing kasus. Marcus Priyo Gunarto mengemukakan bahwa, pidana yang dijatuhkan kepada terdakwa secara umum bertolak dari perbuatan masa lalu dengan tujuan pembalasan, namun apabila berangakat untuk kepentingan akan datang maka tujuan pidananya untuk memperbaiki pelaku. ${ }^{16}$

Pokok pikiran dalam perbuatan pidana, diletakkan pada sifatnya perbuatan dan bukan pada sifatnya orang yang melakukannya. ${ }^{17}$ Berdasarkan itu maka pidana yang berorientasi pada perbuatan sering disebut daad-strafrecht sedangkan pidana yang berorientasi kepada orang disebut dader strafrecht, dan gabungan/kombinasi kedua hal itu sering dinamakan daad-dader-strafrecht. Kombinasi kedua diatas sangat cocok dengan sistem peradilan pidana Indonesia karena fungsi hukum pidana disamping untuk deterrent effect (ide pembalasan) sekaligus perbaikan kelakuan terpidana (ide rehabilitasi) yang merupakan salah satu bagian dari ide keseimbangan.

Fungsi hukum pidana yaitu melindungi dan sekaligus menjaga keseimbangan beberapa aspek kepentingan, baik itu kepentingan masyarakat, negara, pelaku tindak pidana dan korban dari tindak pidana, termasuk juga orang yang menyaksikan kejahatan. ${ }^{18}$ Berbagai kepentingan sebelum menjatuhkan putusan harus masing-

16 Marcus Priyo Gunarto, Sikap Memidana Yang Berorientasi Pada Tujuan Pemidanaan, Jurnal Mimbar Hukum, Fakultas Hukum Universitas Gadjah Mada, Vol 21, No 1 2009, hlm. 100. Dapat diakses pada https://jurnal.ugm.ac.id/jmh/article/view/16248/10794

17Moeljatno, Perbuatan Pidana dan Pertanggungjawaban Dalam Hukum Pidana, Diucapkan Dalam Pidato Upacara Peringatan Dies Natalis ke- 6 Universitas Gadjah Mada, di Sitihinggil Yogyakarta, Pada PanggaL 19 Desember 1955, Bina Aksara, 1983, hlm. 14

${ }^{18}$ Eko Sopoyono, Kebijakan Perumusan Sistem Pemidanaan Yang Berorientasi Pada Korban, Jurnal MasalahMasalah Hukum, Fakultas Hukum Universitas Diponegoro, Masalah-Masalah Hukum Jilid 41, Nomor 1, Tahun 2012, hlm. 30. Dapat diakses pada https://ejournal.undip.ac.id/index.php/mmh/article/view/4157. 
masing terwakili pada tiap putusan. Dengan demikian, keseimbangan dalam menjatuhkan sanksi pidana akan terlihat dari tujuan yang hendak dicapai oleh hukum pidana dalam hal ini hakim yang menjatuhkan putusan.

Theodosios Raymond Alexander mengemukakan bahwa the purpose of sentencing is simply to achieve the aims identified as desirable according to the claimed theoretical justifications for the infliction of punishment. ${ }^{19}$ Tujuan pidana yang hendak dijatuhkan kepada si terdakwa itu bertujuan apa!. Kalaupun ditanya kepada hakim, tujuan apa yang hendak dicapai melalui pidana yang dijatuhkan itu, maka sang hakim sendiri acapkali tidak yakin. Bila didesak juga, maka jawaban berdasarkan suatu asumsi atau harapan belaka. ${ }^{20}$ Sehingga berdampak pada putusan yang tidak proporsional dengan kurang memperhatikan keseimbangan kepentingan antara pelaku, korban, masyarakat pada umumnya. Misalnya yang menjadi salah satu pertimbangan adalah hal-hal yang memberatkan dan meringankan, namun itu pun cenderung prosedural/formalitas yang kadang tidak seusai dengan karakter setiap kasus serta ukuran/batasan dalam menggunakan pertimbangan itu. Dwi Hananta mengungkapkan bahwa, ada beberapa karakteristik yang perlu diperhatikan sebagai hal-hal yang dapat memberatkan maupun yang meringankan pidana dalam putusan hakim, yaitu perbuatan pidana atau tindak pidana, unsur di luar tindak pidana, dan keseriusan atau bahanya dari tindak pidana itu. ${ }^{21}$

Selain karakteristik sebagai penentuan dalam menjatuhkan berat ringanya saksi pidana, maka perlu juga batasan-batasannya untuk menjadi pedoman. James Foy mengemukakan bahwa principle of proportionality... It acts not only as a determining principle in sentencing, guiding the exercise of a trial judge's discretion, but also as a limiting one. ${ }^{22}$ (Principle of proportionality.... berlaku tidak hanya sebagai prinsip penentuan dalam pidana, pedoman pelaksanaan kebijaksanaan hakim dalam persidangan, tetapi juga sebagai batasan).

\footnotetext{
${ }^{19}$ Theodosios Raymond Alexander, A Rational Approach to Sentencing White-Collar Offenders, Australia, Deakin University, 2016, hlm. 12 (Artinya,Tujuan dari pidana hanya untuk mencapai tujuan yang diinginkan sesuai dengan justifikasi teoritis yang diklaim untuk hukuman yang dijatuhkan).

${ }^{20}$ J.E. Sahetapy, Hukum Pidana Indonesia Suatu Perspektif, Bahan Pelatihan/Penataran Asas-asas Hukum Pidana dan Kriminologi, Yogyakarta, diselenggarakan oleh Fakultas Hukum UGM dan Mahupiki, di UGM tanggal 23 - 27 Februari 2014, hlm. 18

21 Dwi Hananta, Pertimbangan Keadaan-Keadaan Meringankan... Op.Cit, hlm. 105-106

22 James Foy, Proportionality in Sentence Appeals: Towards a Guiding Principle of Appellate Review, 23 Canadian Criminal Law Review, 77 (Feb. 2018), hlm. 94. Dapat ditelusuri pada https://papers.ssrn.com/sol3/papers.cfm?abstract_id=3290702
} 
Berdasarkan hal di atas, maka hakim harus bisa menggali lebih dalam peran terdakwa, korban bahkan lingkungan masyarakat sebelum menjatuhkan putusan, dengan demikian maka hakim mendapat banyak masukan supaya memutus suatu perkara dengan proporsional berdasarkan ide keseimbangan. Hal tersebut juga dikemukakan oleh Loebby Loqman yaitu, sejauh mana seorang hakim mendapatkan masukan tentang terdakwa sehingga dia dapat menjatuhkan suatu hukuman yang sesuai dengan keadaan terdakwa tersebut, baik dilihat dari kesalahan atas perbuatan terdakwa maupun tujuan dari pemidanaan bagi diri terdakwa di samping juga memperhatikan pengaruhnya terhadap masyarakat dimana terdakwa melakukan tindak pidana tersebut. ${ }^{23}$

Lengkap atau tidaknya masukan atau informasi yang diterima oleh hakim sangat menentukan berat ringannya putusan pidana yang proporsional. Baik itu dilihat dari unsur perbuatan, kesalahan maupun sanksi pidananya yang dikenal dengan 3 (tiga) masalah pokok dalam hukum pidana. Dalam kasus tertentu memang pelaku telah berhitung untung-rugi sebelum melakukan tindak pidana. Menurut Romli Atmasasmita, setiap pelaku tindak pidana telah memperhitungkan keuntungan dari perbuatannya yang melebihi dari kerugian sebagai akibat perbuatannya. ${ }^{24}$ Apabila terdakwa sudah memperhitungkan keuntungan lebih besar daripada kerugian dengan melakukan tindak pidana, maka sudah sewajarnya dihukum yang sesuai dengan keutungan dan dampak dari perbuatan itu. Misalnya dalam kasus kedua (atas nama TH) di atas, dimana terdakwa melakukan kejahatan karena ingin mendapatkan keuntungan lebih dengan cara mencampur beras. Dengan demikian, putusan dalam kasus ini cenderung tidak proporsional dan mencederai rasa keadilan masyarakat, terutama masyarakat yang membeli beras itu.

Menurut Gregory S. Schneider, ada tiga faktor utama yang memunculkan pidana yang tidak proporsional: ${ }^{25}$

1) Tekanan politik untuk memberlakukan pidana yang lebih keras;

2) Ketidakmampuan badan legislatif untuk merevisi, memperbaiki, dan mengklarifikasi hukum pidana; dan

\footnotetext{
${ }^{23}$ Loebby Loqman, Pemidanaan Yang Bagaimana....Op.Cit, hlm. 576.

${ }^{24}$ Romli Atmasasmita, Asset Recovery dan Mutual Assistance In Criminal Matters, Makalah Untuk Pelatihan Hukum Pidana, Kerjasama Mahupiki Dan Fakultas Hukum UGM, tanggal 23 - 27 Februari 2014, Yogyakarta, hlm. 3-4

25 Gregory S. Schneider, Sentencing Proportionality in the States, USA, Arizona Law Review, Vol. 54, 2012, hlm. 244. Dapat ditelusuri pada http://www.arizonalawreview.org/pdf/54-1/54arizlrev241.pdf
} 
3) Penyalahgunaan kebijakan penuntutan.

Berdasarkan tiga faktor tersebut yaitu, mulai dari tekanan politik, adanya ketidakmampuan legisatif untuk memperbaiki aturan dan penyelahgunaan penuntutan. Namun dalam proses penegakan hukum yang dominan dan menyebabkan putusan hakim tidak proporsional adalah karena tekanan politik dan penyalahgunaan kewenangan punututan. Bahkan beberapa kasus sejak awal sudah ada "setting" dari penuntutan untuk meringankan atau membebaskan terdakwa. Anehnya lagi kadang hakim tidak mengetahui atau bahkan ada juga yang ikut menikmati dengan menyalahgunakan independensinya. Atas dasar itu, yang paling menentukan rangkain penyalahgunaan kewenangan penuntutan sampai putusan adalah hakim karena dia yang menentukan hasil keputusan akhir. Oleh sebab itu, maka harus ada prinsip-prinsip yang menjadi landasan agar putusan hakim menjadi proporsional. Gregory S. Schneider lebih lanjut merinci tentang "proportionality principles" dalam menjatuhkan pidana dapat dikemukakan sebagai berikut: ${ }^{26}$

(1) Apakah hubungan antara pidana dan kejahatan mengejutkan/menggocang (shocks) semua rasa kesopanan yang masuk akal;

(2) Bahayanya dari kejahatan;

(3) Sejarah/riwayat kejahatan terdakwa;

(4) Tujuan legislatif di balik hukuman;

(5) Perbandingan hukuman yang akan dijatuhkan kepada terdakwa dengan yurisdiksi lain apa akan meberlakukan untuk kejahatan yang sama atau mirip; dan

(6) Perbandingan hukuman dengan hukuman lain untuk kejahatan terkait dalam yurisdiksi.

Prinsip proporsional ini mungkin secara universal sama, namun yang menjadi pembeda adalah ada prinsip nilai-nilai ketuhanan yang menjadi pedoman di Indonesia, sehingga putusannya tidak hanya berdasarkan atau berpedoman pada aturan hukum saja tetapi juga berpedoman nilai-nilai religius. Barda Nawawi Arief mengemukakan bahwa, sangat ironis, dalam negara yang ber-Ketuhanan YME dan peradilannya dilakukan "Demi Keadilan berdasarkan Ketuhanan YME", tetapi mahasiswa hukum dan aparat penegak hukumnya hanya tahu tentang keadilan berdasarkan "tuntunan UU”, tetapi tidak tahu tentang keadilan berdasarkan "tutunan

26Ibid, hlm. 250 
Tuhan". ${ }^{27}$ Dengan demikian, tututan Tuhan ini yang seringkali dilupakan oleh hakim, padahal menurut Bismar Siregar bahwa pertanggungjawaban kepada Tuhan Yang Maha Esa haruslah menjadi pertanggungjawaban yang pertama bagi para pemberi keadilan (Hakim) sebagai pagar agar tidak terjadi perasaan hukum yang liar. ${ }^{28}$

Permasalahan pidana dan pemidanaan tidak terlepas dari pemaknaan tindak pidana dan tanggung jawab pidana, sedangkan identifikasi tanggung jawab pidana selalu berlandaskan pada kepentingan pemikiran keseimbangan monodualistik, yaitu adanya keseimbangan kepentingan masyarakat dengan kepentingan individu, termasuk kepentingan subyektif dan obyektif. ${ }^{29}$ Hal itu juga terlihat dalam pertimbangan pada kasus kedua (atas nama $\mathrm{TH}$ ) di atas, hakim telah mempertimbangkan kepentingan individu dalam hal ini pelaku karena telah mengakui perbuatannya, berjanji untuk tidak mengulangi, pencampuran beras tersebut belum berlangsung lama sehingga dirasa layak mendapatkan pidana denda. Namun itu tidak cukup apabila kepentingan masyarakat (pencegahan umum) belum mendapatkan keadilan karena denda yang dijatuhkan pun terlalu ringan begitu juga pengganti denda kalau tidak dibayar yaitu hanya satu bulan kurungan sehingga tidak akan memberikan shock therapy pada pelaku. Dengan demikian, putusan hakim terlalu ringan karena sanksi berupa denda bagi seorang pengusaha dengan bukan seorang pengusaha seyogyanya berbeda. Atas dasar itu maka tidak cukup putusan hakim yang adil secara normatif, tapi perlu filosofi pemidanaan berdasarkan nilainilai ide keseimbangan Pancasila (ketuhanan, kemanusiaan dan kemasyarakatan).

Prinsip pemidanaan yang bercirikan Pancasila harus dilihat secara berimbang dari semua apsek. Hal itu sangat wajar karena sanksi pidana yang dikenal sangat keras, dan terkait langsung dengan hak asasi manusia. Atas dasar itu maka setiap putusan pidana harus dilihat sebagai manusia sebagai individu sekaligus sebagai mahkluk sosial secara berimbang (manusia monodualisme). ${ }^{30}$ Menurut Muladi,

\footnotetext{
27 Barda Nawawi Arief, Pembangunan Sistem Hukum Nasional (Indonesia), Semarang: Pustaka Magister, 2015, hlm. 34

28 Bismar Siregar, Berbagai Segi Hukum dan Perkembangannya Dalam Masyarakat, Bandung,Alumni, 1983, hlm.36 ${ }^{29}$ Indriyanto Seno Adji, Administrative Penal Law: "Kearah Konstruksi Pidana Limitatif", Bahan Untuk Pelatihan Hukum Pidana, Yogyakarta, Kerjasama Mahupiki dan Fakultas Hukum UGM, tanggal 23 - 27 Februari 2014, hlm. 5 30 Marcus Priyo Gunarto, Asas Keseimbangan Dalam Konsep Rancangan Undang-Undang Kitab Hukum Pidana, Jurnal Mimbar Hukum, Fakultas Hukum Universitas Gadjah Mada, Vol 22, No 1 2012, hlm. 87. Dapat diakses pada https://jurnal.ugm.ac.id/jmh/article/view/16143/10689
} 
dalam pengaturan tindak pidana, implementasi ide keseimbangan sangat diperhatikan. Hal itu dapat disebutkan berikut ini, yaitu: ${ }^{31}$

1. Keseimbangan antara moralitas institusional; moralitas sosial dan moralitas individual;

2. Keseimbangan antara "individual rights" dan "collective rights";

3. Keseimbangan antara kepentingan si pelaku dengan korban;

4. Keseimbangan antara aspek obyektif (perbuatan) dengan aspek subyektif (sikap batin);

5. Keseimbangan antara kepastian hukum, kelenturan dan keadilan;

6. Keseimbangan antara nilai-nilai nasional dan nilai-nilai universal;

7. Keseimbangan antara legalitas formal dan legalitas material yang memberi ruang pada "the living law", yang bersumber pada:

a. kebijakan legislatif paska kemerdekaan;

b. interaksi dan kesepakatan ilmiah dalam pelbagai pertemuan ilmiah nasional;

c. aspirasi sosiologis;

d. aspirasi universal masyarakat beradab.

Atas dasar itu maka setiap putusan hakim harus mencerminkan secara proporsional berdasarkan ide keseimbangan di atas, yang secara singkat dapat dikatakan bahwa pidana yang logis, cocok dan wajar yang dijatuhkan kepada pelaku. Theodosios Raymond Alexander mengemukakan bahwa, proportionality requires courts to impose sentences that bear a reasonable, or proportionate, relationship to the criminal conduct in question. Courts are required to impose a sentence on an offender which is of a severity that reflects the objective seriousness of the offence. ${ }^{32}$ (Proporsionalitas menuntut pengadilan untuk menjatuhkan pidana yang wajar atau proporsional, sehubungan dengan tindak pidana yang tersebut. Pengadilan diharuskan untuk menjatuhkan pidana kepada pelaku yang memiliki tingkat kekejaman yang mencerminkan keseriusan dari kejahatan). Intinya hakim harus tau kapan menjatuhkan pidana yang sesuai bagi pelaku dan kapan menjatuhkan putusan untuk tidak menghukum berdasarkan ide keseimbangan itu.

Khusus dalam kasus kedua (atas nama HT) di atas, sebagian juga belum mencerminkan ide keseimbangan, yaitu antara kepentingan pelaku dengan masayarakat. Dijatuhkan pidana denda merupakan perlindungan kepentingan pelaku

31 Muladi, Beberapa Catatan Terhadap RUU KUHP, dalam Beberapa Tulisan Terkait Kebijakan Kriminal dalam RUU KUHP, Sebagai Bahan Bacaan untuk Focus Group Discussion yang diselenggarakan Lembaga Studi dan Advokasi Masyarakat (ELSAM) dengan tema: "Melihat Politik Kodifikasi dalam Rancangan KUHP", 28 September 2006, Jakarta, Democratic Reform Support Program (RRSP) dan Aliansi Nasional Reformasi KUHP, 2006, hlm. 10

32 Theodosios Raymond Alexander, A Rational Approach to Sentencing,...Op.Cit, hlm. 31 
karena hakim memandang tujuan pidana bukan hanya membalas tapi juga memperbaiki, akan tetapi kepentingan masyarakat kurang terpenuhi karena menjatuhkan denda yang ringan dari ancaman maksimal sehingga tidak memberikan peringatan atau pencegahan pada masyarakat. Selain itu juga belum maksimal mencerminkan ide keseimbangan antara kepastian hukum, kelenturan dan keadilan karena rasa keadilan yang belum dipertimbangkan secara lengkap, termasuk keadilan pada masyarakat beserta dampak sosialnya. Dalam masyarakat Indonesia tidak cukup suatu putusan itu adil secara hukum, tetapi juga harus adil secara moral institusional, adil secara moral sosial dan adil secara moral individu berdasarkan nilai-nilai nasional maupun universal.

Mungkin menjadi pertanyaan, kenapa kepentingan masyarakat yang belum mendapatkan keadilan dalam suatu putusan hakim harus menjadi perhatian bagi Hakim. Mengutip pernyataan Suteki, dari kaca mata sosiologis seorang hakim bukanlah sosok yang bebas dan netral ${ }^{33}$ karena terikat dengan berbagai atribut sosial yang melingkupinya. Dasar pemikiran Suteki tersebut menggunakan teori Bekerjanya Hukum dalam masyarakat yang dikemukakan oleh William J Chambliss dan Robert B.Seidman. Lebih lanjut menurut Suteki ${ }^{34}$ :

Persepsi kita harus diluruskan bahwa pengadilan harus kita pandang sebagai Institusi Sosial sehingga secara prinsip pengadilan juga tidak bersifat steril dari pengaruh luar institusi tersebut. Dalam melakukan pekerjaannya, Pengadilan, khususnya hakim akan dipengaruhi oleh faktor-faktor yang berada di luar dan di dalam institusi tersebut. Faktor dari dalam berupa sumber daya manusia, tata organisasi, budaya lingkungan kerja, sumber daya materiil (ekonomi), sistem manajemen, kepemimpinan dll. Faktor dari luar bisa berupa interkasi antarlembaga penegak hukum lainnya, serta masyarakat sebagai pengguna jasa pengadilan.

Sehingga sebagai konsekuensinya, hakim dalam putusannya haruslah memperhatikan kepentingan masyarakat sebagai pengguna jasa pengadilan untuk memperoleh keadilan. Jika merujuk pada kasus kedua (atas nama TH), kerugian yang dialami masyarakat sebagai konsumen belum mendapat perhatian yang lebih dari hakim dalam putusannya. Selain itu, hal yang juga dianggap menciderai keadilan

\footnotetext{
${ }^{33}$ Suteki, Masa Depan Hukum Progresif, Yogyakarta, Thafamedia, 2015, hal. 83
}

34 Ibid, hal.85 
masyarakat adalah terkait salah satu alasan hakim menjatuhkan denda kepada terdakwa yaitu:

"motif terdakwa selaku pelaku usaha melakukan pencampuran beras adalah bukan semata-mata mencari keuntungan namun karena tingginya permintaan dari Konsumen di pasaran terhadap beras Bulog Premium $5 \mathrm{Kg}$, karena Bulog tidak lagi mengeluarkan Beras Premium $5 \mathrm{Kg}$ namun hanya Beras Bulog Premium $50 \mathrm{Kg}$, sehingga masyarakat kecil tidak sanggup membeli untuk membeli Beras Bulog Premium $50 \mathrm{Kg}$ ".

Di satu sisi, tindakan pelaku usaha tersebut haruslah dilihat sebagai tindakan pelaku usaha yang tidak memiliki itikad baik dalam melakukan kegiatan usahanya, dimana hal tersebut merupakan kewajiban bagi pelaku usaha sebagaimana diatur dalam ketentuan Pasal Pasal 7 huruf a UU Perlindungan konsumen. Tindakan pelaku usaha yang mencampur beras tersebut rasanya sulit diterima dengan logika umum bahwa tindakan tersebut bukanlah untuk mencari keuntungan, karena hal tersebut sejalan dengan dasar prinsip ekonomi pelaku usaha adalah mendapat keuntungan yang semaksimal mungkin dengan modal seminimal mungkin. Prinsip ini lah yang sangat potensial merugikan kepentingan konsumen, baik secara langsung maupun tidak langsung. Kondisi ini jelas menunjukkan kedudukan pelaku usaha dan konsumen menjadi tidak seimbang dan konsumen berada pada posisi yang lemah. Hal ini seharusnya menjadi alasan pemberat bagi hakim dalam memberikan sanksi kepada terdakwa dengan menjatuhkan pidana denda serta pidana pengganti kurungan yang tinggi apabila denda tidak dibayar.

Apabila melihat fungsi hakim dalam kedudukannya sebagai pemberi keadilan, maka dapat ditemukan dalam pasal 5 ayat 1 UU Nomor 48 Tahun 2009 tentang Kekuasaan Kehakiman, yang berbunyi bahwa "hakim dan hakim konstitusi wajib menggali, mengikuti, dan memahami nilai-nilai hukum dan rasa keadilan yang hidup dalam masyarakat. Selanjutnya dalam penjelasan pasal tersebut "Ketentuan ini dimaksudkan agar putusan hakim dan hakim konstitusi sesuai dengan hukum dan rasa keadilan masyarakat". Budiono Kusumohamidjojo lebih tegas lagi melihat relasi rasa keadilan hakim dan rasa keadilan masyarakat, bahwa semakin besar kesenjangan antara rasa keadilan hakim dan rasa keadilan masyarakat, semakin 
besar juga ketidakpedulian masyarakat kepada hukum. ${ }^{35}$ Lebih lanjut menurut Budiono $^{36}$ :

Rasa keadilan yang dirumuskan oleh hakim yang mengacu kepada pengertianpengertian serta aturan-aturan yang baku dengan cara demikian dapat dipahami oleh masyarakat, yang pada giliran berikutnya berpeluang untuk ikut menghayati (sharing) rasa keadilan yang dirumuskan oleh hakim itu dalam keputusannya. Rasa keadilan yang diketengahkan hakim lalu dapat menjadi rasa keadilan yang juga dirasakan oleh masyarakat.

Berdasarkan hal tersebut maka suatu putusan hakim adil hanya berlandasakan legalitas formal tanpa mempertimbangkan hukum yang hidup ditengah masyarakat maka akan terjadi anarki. Sehingga dengan dijatuhkan putusan oleh hakim dengan harapan mencari keadilan malah justru menimbulkan ketidakadilan seperti dalam putusan kasus pertama (atas nama BNM) di atas. Dampak ketidakadilan secara moral sosial maka dampaknya masyarakat akan bertindak atas ketidakadilan itu. Soedikno Mertokusumo mengemukakan bahwa dalam menegakkan hukum ada tiga unsur yang harus selalu diperhatikan secara proporsional seimbang, yaitu kepastian hukum (Rechtssicherheit), kemanfaatan (Zweckmassigkeit), keadilan (Gerechtigkeit). Lebih lanjut Sudikno mengemukakan bahwa ${ }^{37}$ dalam menegakkan hukum harus ada kompromi antara ketiga unsur tersebut. Ketiga unsur itu harus mendapat perhatian secara proporsional seimbang. Tetapi dalam praktek tidak selalu mudah mengusahakan kompromi secara proporsional seimbang antara ketiga unsur tersebut.

Ketidakadilan secara moral muapun dalam nilai-nilai nasional maupun universal itu dapat dirasakan bukan hanya pada masyarakat, tetapi itupun juga dirasakan oleh Presiden Joko Widodo dengan dibuktikan dalam pemberian amnesti kepada BNM (kasus pertama di atas). Dengan demikian, pemberian amnesti oleh Presiden ini merupakan peringatan bagi semua hakim agar mempertimbangkan berbagai aspek agar setiap putusan dapat dipertanggungjawabkan untuk semua baik untuk korban, pelaku, masyarakat dan negara sehingga putusannya proporsional berdasarkan ide keseimbangan.

\footnotetext{
35 Budiono Kusumohamidjojo, Ketertiban Yang Adil "Problematika Filsafat Hukum", Jakarta, Gramedia Widiasarana Indonesia, 1999, hlm.145 36 Ibid

37 Soedikno Mertokusumo, Mengenal Hukum (Suatu Pengantar), Yogyakarta, Liberty, 1991, hlm. 135
} 


\section{PENUTUP}

\subsection{Kesimpulan}

Berdasarkan uraian yang telah dikemukakan di atas, sebagai kesimpulan dalam tulisan ini yaitu sebagai berikut:

1. Dasar pertimbangan hakim dalam memutus perkara berdasarkan hukum dan keyakinannya terlalu mengutamakan legalitas formal sehingga dampaknya yang terjadi ketidakadilan. Seolah hukum diartikan sebatas norma yang tertulis, dan apabila rumusan norma itu sudah terpenuhi maka sudah bisa dikenakan pidana seperti terlihat dalam Putusan Pengadilan No.574 K/Pid.Sus/2018/MA dan Putusan No. 83 PK/PID.SUS/2019. Namun sebaliknya, apabila hakim menjatuhkan putusan pidana pun terlihat kurang mempertimbangan keadilan bagi korban (masyarakat) serta dampak sosial dari putusan itu, sehingga putusannya tidak proporsional karena kerugian yang dialami masyarakat dengan pidana yang dijatuhkan cenderung tidak memberikan deterrent effect atau shock therapy kepada palaku sebagaimana terlihat dalam Putusan Pengadilan No 374/Pid.Sus/2017/PN.Tpg.

2. Konsep proporsionalitas putusan hakim berdasarkan ide keseimbangan yaitu, pertama keseimbangan antara legalitas formal dan hukum yang hidup di masyarakat karena hakim harus mampu menggali nilai-nilai hukum di masyarakat baik hukum adat maupun hukum agama karena menegakkan hukum tidak cukup dengan menegakkan norma, maka perlu memperhatikan hukum yang hidup. Kedua, keseimbangan antara aspek kepastian hukum, kelenturan dan keadilan, yaitu hakim tidak boleh semata-mata mengejar kepastian hukum apabila berbenturan dengan keadilan karena hukum hakikatnya adalah keadilan. Ketiga aspek keseimbangan antara kepentingan si pelaku dengan korban (masyarakat) yaitu hakim harus memperhatikan kepentingan masyarakat yang dirugikan beserta dampaknya atas perbuatan pidana itu. Namun juga harus memperhatikan kepentingan pelaku sebagai seorang manusia yang kemungkinan prilaku itu bisa diperbaiki (melihat kedepan), disamping memberikan sanksi pembalasan yang sesuai atas perbuatan pelaku yang bertujuan untuk menyadarkan atas kesalahannya. 


\subsection{Saran}

1. Harus segera dirumsukan pedoman dan tujuan pemidanaan dalam UU Kekuasaan Kehakiman agar hakim dalam menjatuhkan pidana lebih terarah.

2. Perlu pendidikan/pelatihan bagi aparat penegak hukum khususnya hakim agar melihat hukum bukan hanya sebatas norma tetapi juga nilai yang terkadung dibalik norma.

3. Permasalahan penegakan hukum kadang bukan hanya kekeliriuan/kesalahan aparat dalam menegakkan hukum, tapi juga bisa karena undang-undangnya, maka harus segera direvisi khususnya UU No. 11 Tahun 2008 tentang Informasi dan Transaksi Elektronik.

\section{DAFTAR PUSTAKA}

\section{Buku dan Jurnal}

Barda Nawawi Arief, Pembangunan Sistem Hukum Nasional (Indonesia), Semarang: Pustaka Magister, 2015.

Bismar Siregar, Berbagai Segi Hukum dan Perkembangannya Dalam Masyarakat, Bandung, Alumni, 1983

Budiono Kusumohamidjojo, Ketertiban Yang Adil "Problematika Filsafat Hukum", Jakarta, Gramedia Widiasarana Indonesia, 1999

Dwi Hananta, Pertimbangan Keadaan-Keadaan Meringankan Dan Memberatkan Dalam Penjatuhan Pidana, Jurnal Hukum dan Peradilan, Volume 7, Nomor 1 Maret 2018.

Eko Sopoyono, Kebijakan Perumusan Sistem Pemidanaan Yang Berorientasi Pada Korban, Jurnal Masalah-Masalah Hukum, Fakultas Hukum Universitas Diponegoro, MasalahMasalah Hukum Jilid 41, Nomor 1, Tahun 2012. Dapat diakses pada https://ejournal.undip.ac.id/index.php/mmh/article/view/4157.

Gregory S. Schneider, Sentencing Proportionality in the States, USA, Arizona Law Review, Vol. 54, 2012. Dapat ditelusuri pada http://www.arizonalawreview.org/pdf/541/54arizlrev241.pdf

Indriyanto Seno Adji, Administrative Penal Law: "Kearah Konstruksi Pidana Limitatif", Bahan Untuk Pelatihan Hukum Pidana, Yogyakarta, Kerjasama Mahupiki dan Fakultas Hukum UGM, tanggal 23 - 27 Februari 2014. 
J.E. Sahetapy, Hukum Pidana Indonesia Suatu Perspektif, Bahan Pelatihan/Penataran Asasasas Hukum Pidana dan Kriminologi, Yogyakarta, diselenggarakan oleh Fakultas Hukum UGM dan Mahupiki, di UGM tanggal 23 - 27 Februari 2014.

James Foy, Proportionality in Sentence Appeals: Towards a Guiding Principle of Appellate Review, 23 Canadian Criminal Law Review, 77 (Feb. 2018). Dapat ditelusuri pada https://papers.ssrn.com/sol3/papers.cfm?abstract_id=3290702

Kamus Besar Bahasa Indonesia (KBBI), dapat ditelusuri pada https://www.kbbi.web.id/proporsional

Loebby Loqman, Pemidanaan Yang Bagaimana, Jurnal Hukum dan Pembangunan, Fakultas Hukum Universitas Indonesia, Vol 14, No 6, 1984. Dapat diakses pada http://jhp.ui.ac.id/index.php/home/article/view/1088/1011

Marcus Priyo Gunarto, Asas Keseimbangan Dalam Konsep Rancangan Undang-Undang Kitab Hukum Pidana, Jurnal Mimbar Hukum, Fakultas Hukum Universitas Gadjah Mada, Vol 22, No 12 2012. Dapat diakses pada https://jurnal.ugm.ac.id/jmh/article/view/16143/10689

---------, Sikap Memidana Yang Berorientasi Pada Tujuan Pemidanaan, Jurnal Mimbar Hukum, Fakultas Hukum Universitas Gadjah Mada, Vol 21, No 1 2009. Dapat diakses pada https://jurnal.ugm.ac.id/jmh/article/view/16248/10794

Markus D. Dubber, An Introduction to the Model Penal Code, United States of America, Oxford University Press, 2015.

Moeljatno, Perbuatan Pidana dan Pertanggungjawaban Dalam Hukum Pidana, Diucapkan Dalam Pidato Upacara Peringatan Dies Natalis ke- 6 Universitas Gadjah Mada, di Sitihinggil Yogyakarta, Pada Tangga; 19 Desember 1955, Bina Aksara, 1983.

Muladi, Beberapa Catatan Terhadap RUU KUHP, dalam Beberapa Tulisan Terkait Kebijakan Kriminal dalam RUU KUHP, Sebagai Bahan Bacaan untuk Focus Group Discussion yang diselenggarakan Lembaga Studi dan Advokasi Masyarakat (ELSAM) dengan tema: "Melihat Politik Kodifikasi dalam Rancangan KUHP", 28 September 2006, Jakarta, Democratic Reform Support Program (RRSP) dan Aliansi Nasional Reformasi KUHP, 2006.

Romli Atmasasmita, Asset Recovery dan Mutual Assistance In Criminal Matters, Yogyakarta, Makalah Untuk Pelatihan Hukum Pidana, Kerjasama Mahupiki Dan Fakultas Hukum UGM, tanggal 23 - 27 Februari 2014.

Shidarta, Argumentasi Hakim Dalam Beberapa Contoh Kasus Penodaan Agama, 2018, Dapat ditelusuri pada https://business-law.binus.ac.id/2018/07/10/argumentasi-hakimdalam-beberapa-contoh-kasus-penodaan-agama/ 
Endri dkk, Proporsionalitas Putusan Hakim Berdasarkan Ide,

Soedikno Mertokusumo, Mengenal Hukum (Suatu Pengantar), Yogyakarta, Liberty, 1991.

Suteki, Masa Depan Hukum Progresif, Yogyakarta, Thafamedia, 2015.

Theodosios Raymond Alexander, A Rational Approach to Sentencing White-Collar Offenders, Australia, Deakin University, 2016.

\section{Putusan Pengadilan}

Pengadilan Negeri Tanjungpinang No. 374 /Pid.Sus/ 2017/ PN.Tpg atas nama TH alias A

Putusan Kasasi Mahkamah Agung No.574 K/Pid.Sus/2018/MA atas nama BNM

Putusan Pengadilan Negeri Mataram pada tanggal 26 Juli 2017, No. 256/ Pid. sus/PN Mtm atas nama BNM

Putusan Peninjauan Kembali Mahkamah Agung No. 83 PK/PID.SUS/2019 atas nama BNM 